\title{
Hetero-cellular interaction between cancer cells and stem cells in cancer metastasis
}

\author{
Jamal El Saghir, Ali Bazarbachi, Youmna Kfoury, Marwan El-Sabban \\ From 15th International Conference on Human Retroviruses: HTLV and Related Viruses \\ Leuven and Gembloux, Belgium. 5-8 June 2011
}

\section{Background}

Metastasis, the most devastating aspect of cancer, is a multistep process by which cancer cells colonize secondary organ sites. Study of cellular and molecular determinants of cancer cells should be considered in the context of a complex micro-environment including hetero-cellular interactions that may influence disease progression. Stem cells, in the tumor micro-environment, are emerging as critical players in the acquisition of the invasive and metastatic phenotype.

\begin{abstract}
Aim
In this study, we assessed the role of paracrine and direct cell-cell interactions between human MSCs and Adult Tcell Leukemia/Lymphoma cells (HuT-102). We studied the transcriptomic modification induced by this reciprocal interaction and the role of connexin expression and gap junctional intercellular communication in modulating the potential of cancer cells to invade and metastasize.
\end{abstract}

\section{Methods}

Trypan Blue exclusion assays cell counting and RealTime PCR were performed to assess cancer cell proliferation and gene expression in indirect co-culture experiments. Endothelial monolayer invasion, cell communication assays and live imaging were performed to study the role of gap junctions in the direct cancer cellstem cell interaction.

\section{Results}

In a Trans-well co-culture system, MSCs (in insert) induced a decrease in HuT-102 proliferation while MSCs (in well) induced an increase in HuT-102

\footnotetext{
* Correspondence: me00@aub.edu.lb Department of Anatomy, Cell Biology, and Physiology, Department of Internal Medicine, Faculty of Medicine, American University of Beirut, Beirut, Lebanon
}

(c) 2011 El Saghir et al; licensee BioMed Central Ltd. This is an open access article distributed under the terms of the Creative Commons Attribution License (http://creativecommons.org/licenses/by/2.0), which permits unrestricted use, distribution, and reproduction in any medium, provided the original work is properly cited. proliferation. VEGF and SDF-1 expression in MSCs (well) along with CXCR4 expression in HuT-102 (insert) was significantly up-regulated, leading to a marked increase in HuT-102 proliferation. Connexins were shown to be expressed in MSCs and HuT-102 and to facilitate the direct interaction between the two cell types. Induction of gap junctional intercellular communication is correlated with a 5 -fold increase in HuT-102 trans-endothelial cell migration.

\section{Conclusion}

Stem cells, in the tumor niche, and cancer cells reciprocally modulate each others phenotype and function, in a context-dependent manner, reinforcing the importance of tumor cellular micro-environment in cancer invasion and metastasis.

Published: 6 June 2011

\section{doi:10.1186/1742-4690-8-S1-A173}

Cite this article as: El Saghir et al:: Hetero-cellular interaction between cancer cells and stem cells in cancer metastasis. Retrovirology 20118 (Suppl 1):A173.

Submit your next manuscript to BioMed Central and take full advantage of:

- Convenient online submission

- Thorough peer review

- No space constraints or color figure charges

- Immediate publication on acceptance

- Inclusion in PubMed, CAS, Scopus and Google Scholar

- Research which is freely available for redistribution 